\title{
PEMBINAAN KESEHATAN MENTAL TERHADAP EKS WANITA TUNASUSILA
}

\author{
Hasneli \\ Fakultas Ushuluddin IAIN Imam Bonjol Padang \\ Email: has_neli@ymail.com
}

\begin{abstract}
Abstrak
Tulisan ini dimaksuddkan untuk mengkaji fenomena perilaku wanita tunasusila. Wanita tunasusila melakukan perilaku dengan penyebab, baik internal maupun ekternal. Mereka yang memilih meninggalkan perilaku tunasusila patut mendapatkan apresiasi. Kepada mereka dapat diberikan sejumlah bimbingan agar benar-benar dapat menjalani kehdupan barunya secara sukses, di antaranya adalah bimbingan untuk mendapatkan kesehatan psokologis, fisik, sosial dan bimbingan agama. Di samping itu juga dibekali dengan bimbingan keterampilan.
\end{abstract}

Kata kunci: kesehatan mental, bimbingan

Pendahuluan

Permasalahan dekadensi moral saat ini sudah semakin membahayakan dengan semakin banyaknya peristiwa kejahatan yang dilakukan oleh masyarakat. Mulai dari pencurian, penjarahan, perampokan, perzinahan, penipuan, pemerkosaan, pelecehan seksual, perjudian, dan masih banyak lagi, termasuk pembunuhan. Yang jelas fakta membuktikan bahwa semakin hari semakin banyak saja yang menjadi korbannya sebagai akibat dari menurunnya kualitas moral masyarakat.

Kemajuan ilmu pengetahuan dan teknologi serta arus globalisasi yang melanda dunia saat ini cukup berpengaruh terhadap tingginya permasalahan sosial. Manusia dalam perkembangan kehidupannya tentunya ingin yang terbaik, menjalani hidup sesuai yang diharapkan dan dapat bertindak sesuai dengan norma-norma yang berlaku. Tetapi manusia sering menemui hambatanhambatan dalam kehidupannya, sehingga mereka kecewa dan mencari jalan keluar yang tidak tepat. Sejalan dengan hal ini, studi kesehatan mental merekomendasikan bahwa tidak sedikit manusia terjerumus dalam gejala the agony of modernization (azab sengsara karena modernisasi).

Gejala The agony of modernization merupakan suatu bentuk ketegangan psikososial yang menjadi penyakit manusia dalam memerankan perilakunya dalam kehidupan sosial, seperti meningkatnya kriminalitas, kemaksiatan, tindak kekerasan, perkosaan, prostitusi, gangguan jiwa, bunuh diri, dan sebagainya (Hawari, 1997). Refleksi psikososial ini disebabkan oleh semakin modernnya suatu masyarakat, maka semakin bertambahnya intensitas dan eksistensitas dari berbagai disorganisasi dan disintegrasi sosial dalam realitas. Kebenaran-kebenaran abadi sebagaimana yang terkandung dalam ajaran agama, pola hidup dan konsepsi masyarakat telah bergeser dan disisihkan, sehingga orang berpegang pada kebutuhan materi dan tujuan sesaat. Sebagaimana juga dengan profesi wanita tunasusila yang dianggap sangat tabu di masyarakat, mengingat negara kita adalah negara dengan adat ketimuran dan memiliki norma - norma yang sangat kental di masyarakat. Akibatnya, tidak jarang para wanita tunasusila mendapat cemooh dan hinaan dari masyarakat. Apalagi apabila keluarga yang bersangkutan telah mengetahuinya. Hal tersebut tentu akan sangat berpengaruh terhadap kondisi psikologis mantan wanita tunasusila yang bersangkutan. 
Pembahasan ini diarahkan pada masalah yang berhubungan dengan alasan seseorang yang bekerja sebagai wanita tunasusila, bagaimana kondisi psikologis mereka dan bagaimana pembinaan yang diberikan pada mantan wanita tunasusila, agar dapat melepaskan diri dari pekerjaan terlarang tersebut dan dapat meningkatkan taraf kesehatan yang bersangkutan, tidak hanya pada kesehatan fisik, tetapi juga kesehatan psikologis, sosial dan spiritual (agama).

\section{Konsep Perilaku Wanita Tunasusila atau Prostitusi}

Istilah WTS (Wanita Tunasusila) di dalam masyarakat dikenal juga dengan sebutan prostitusi, pelacur, Pekerja Seks Komersial (PSK), kupu-kupu malam, lonte, sampah masyarakat, perempuan nakal dan lain-lain. Secara legal Pemerintah Indonesia mengeluarkan Surat Keputusan Menteri Sosial No. 23/HUK/96 yang menyebut pelacur dengan istilah WTS (Koentjoro, 2004). Penggunaan tuna susila sebagai istilah resmi bagi pelacur perempuan, merupakan upaya pemerintah untuk memperhalus istilah pelacuran. Sedang pelacur laki-laki disebut gigolo (Kartono, 2009).

Pelacuran atau prostitusi berasal dari bahasa Latin, pro-stituree atau pro-stauree, yang berarti membiarkan diri berbuat zina, melakukan persundalan, percabulan, dan pergendakan (Kartono, 2009). Terdapat berbagai definisi tentang WTS, di antaranya menurut Kamus Umum Bahasa Indonesia WTS adalah perempuan jalang, perempuan pelacur (Poerwadarminta, 1987). Sedang menurut Kartono (2009), WTS atau pelacur adalah "wanita yang mempunyai kebiasaan melakukan hubungan kelamin di luar perkawinan, baik dengan imbalan jasa maupun tidak". Hampir senada dengan definisi di atas, Bonger (Kartono, 2009) yang menyebutkan bahwa prostitusi adalah gejala kemasyarakatan di mana wanita menjual diri melakukan perbuatan-perbuatan seksual sebagai mata pencarian. Berdasarkan beberapa definisi di atas, dapat dipahami bahwa di dalam istilah prostitusi terkandung pengertian adanya peristiwa penjualan diri sebagai profesi atau mata pencarian sehari-hari dengan cara melakukan relasirelasi seksual.

Profesi prostitusi atau WTS merupakan salah satu bentuk penyakit masyarakat yang harus dihentikan penyebarannya, tanpa mengabaikan usaha pencegahan dan perbaikan. Tuna susila diartikan sebagai perilaku kurang beradab karena keroyalan relasi seksualnya dalam bentuk penyerahan diri pada banyak laki-laki untuk pemuasan seksual dan mendapatkan imbalan jasa atau uang bagi pelayanannya (Kartono, 2009). Dengan demikian dapat dipahami bahwa prostitusi dilakukan wanita pekerja seks komersial yang menjual diri kepada seseorang untuk memuaskan nafsu seks dan mendapatkan imbalan.

Motivasi menjadi WTS adakalanya karena terpaksa (faktor eksternal) misalnya karena himpitan ekonomi, tidak memiliki keterampilan dan keahlian lain, terjebak oleh tipuan agen tenaga kerja, dan lainlain. Selain itu, ada pula yang melakukannya secara tidak terpaksa (faktor internal), misalnya keinginan sendiri untuk mencari pasangan yang sesuai dengan kriterianya, atau karena terlanjur berbuat, seorang perempuan biasanya berpendapat sudah tidak ada lagi yang dapat dibanggakan dalam dirinya, maka ia akan merasa putus asa dan mencari pelampiasan, sehingga dia memutuskan untuk tetap melakukan perbuatan bejatnya itu, dan lain-lain.

WTS yang menjalankan profesinya secara terpaksa akan menimbulkan gangguan psikologis berupa dihantui perasaan bersalah dan menurunnya rasa percaya diri sehingga merasa sungkan dalam bergaul dalam masyarakat. Sedangkan yang menjalankan profesinya secara tidak terpaksa akan menimbulkan efek kecanduan dan merasa tidak pernah puas dengan pasangan seks sebelumnya, sehingga ia akan terus mencari pasangan yang sesuai dengan kriterianya.

Di tengah upaya berbagai daerah untuk memberantas prostitusi, belakangan ini justru terungkap makin maraknya praktik prostitusi terselubung yang makin canggih. Meskipun 
praktik prostitusi di lokalisasi telah berkurang secara drastis, namun kegiatan prostitusi muncul dalam bentuk lain seperti prostitusi online dan bahkan sampai melibatkan perempuan di bawah umur (Suyanto, 2015). Wanita-wanita pelacur kebanyakan ada di kota-kota, daerah-daerah lintas para turis dan tempat-tempat plesir, di mana banyak didatangi oleh orang-orang yang hendak berlibur. Pada umumnya di tempat-tempat tersebut diterapkan prinsip 4-S dari tourisme, yaitu sea (laut dan adanya air), sun (ada matahari), service (pelayanan) dan sex. Maka untuk menyelenggarakan pelayanan seks guna pemuasan kebutuhan baik dari kaum laki-laki maupun kaum perempuannya, diselenggarakan praktik-praktik pelacuran secara resmi di rumah-rumah bordil dan lokasi tertentu, ataupun secara tidak resmi merembes ke hotel-hotel, penginapanpanginapan dan tempat-tempat hiburan (Kartono, 2009).

Adapun motif yang melatarbelakangi tumbuh dan berkembangnya prostitusi diantaranya adalah upaya untuk menghindarkan diri dari kesulitan hidup dan mendapatkan kesenangan melalui jalan pendek (Kartono, 2009). Di samping itu tidak adanya undang-undang yang melarang orang malakukan prostitusi dan juga tidak ada larangan terhadap orang-orang yang melakukan relasi seks di tempat tertutup (Djubaedah, 2003). Selanjutnya dalam sumber yang sama diketahui bahwa RUU-KUHP hanya melarang orang yang bergelandangan dan berkeliaran di jalan atau di tempat umum dengan tujuan melacurkan diri, sementara pelacuran dan prostitusi itu sendiri tidak dilarang. Sebab jika terdapat dalam RUU-KUHP tentang pelarangan prostitusi, tentu pelacuran dalam bentuk apapun, oleh siapapun, dan di tempat manapun tetap dilarang termasuk juga pelacuran di tempat tertutup. Dengan demikian dapat dikatakan bahwa prediket pelacur bukan hanya untuk wanita saja, tetapi juga untuk laki-laki yang melakukan hubungan kelamin di luar perkawinan ( Kartono, 2009).

Wanita tuna susila harus ditanggulangi tidak saja melalui kerjasama dengan pemerintah yang memberikan pembinaan bagi mantan pekerja seks tapi perlindungan hukum bagi perempuan juga berperan penting. Sebagaimana yang terjadi di Indonesia, masalah wanita tuna susila makin berkembang gerak dan bentuknya menjadi suatu sistem mata pencaharian yang bertentangan dengan ajaran agama dan falsafah negara yaitu Pancasila dan UUD 1945. Oleh karena itu, pemerintah dalam hal ini Departemen Sosial berusaha untuk merehabilitasi mantan WTS agar dapat hidup layak dan sejahtera sehingga dapat berpartisipasi dalam usaha-usaha kesejahteraan sosial. Hal ini sebagai realisasi dari Ketentuan-ketentuan Pokok Kesejahteraan Sosial, pasal 1 yang berbunyi: "Setiap warga negara berhak atas taraf hidup kesejahteraan sosial yang sebaik-baiknya dan berkewajiban untuk sebanyak mungkin ikut serta di dalam usaha-usaha kesejahteraan sosial" (Undang-Undang RI No. 6 Tahun 1974).

\section{Faktor-faktor yang Berpengaruh Terhadap Perilaku Prostitusi}

Tumbuh dan berkembangnya perilaku prostitusi disebabkan oleh beberapa faktor, di antaranya faktor ekonomi, pendidikan keluarga, dan pengaruh lingkungan masyarakat. Untuk lebih jelasnya dapat diuraikan di bawah ini:

Pertama: Faktor Ekonomi. Krisis moneter dan ekonomi telah memberi dampak sistemik bagi kehidupan masyarakat, utamanya dalam aspek ekonomi. Hal tersebut tentu mengakibatkan semakin meningkatnya jumlah pengangguran dan akhirnya menjadi faktor pendorong bagi tenaga kerja untuk mengerjakan apapun untuk mendapatkan uang walaupn bertentangan dengan hukum, moral, dan etika. Kondisi tersebut dibarengi dengan kebutuhan yang semakin lama semakin mendesak, sehingga banyak kaum wanita yang menjadi pelacur untuk menghindarkan diri dari kesulitan hidup (Kartono, 2009). 
Oleh sebab itu dapat dikatakan seseorang menjadi WTS itu dikarenakan oleh adanya tekanan ekonomi, yaitu kemiskinan yang dirasakan terus menerus dan adanya kesenjangan sosial, satu pihak penumpukan kekayaan pada golongan atas, di lain pihak terjadinya kemelaratan pada golongan bawah. Bagi pengusaha rumah pelacuran mencari-cari wanitawanita pelacur dari kelas melarat karena kebanyakan wanita tuna susila berasal dari keluarga miskin dengan pendidikan rendah. Selain itu terdapat juga aspirasi materil yang tinggi pada diri wanita. Kesenangan dan ketamakan terhadap pakaian-pakaian indah dan perhiasan mewah, tetapi tidak mau bekerja (Kartono: 2009).

Kedua: Faktor Pendidikan Lingkungan Keluarga. Lingkungan keluarga merupakan lingkungan pendidikan pertama dan utama bagi anak untuk mendapatkan pendidikan dan bimbingan. Karena sebagian besar waktu anak berada dalam lingkungan keluarga. Karenanya, pendidikan paling banyak diterima oleh anak dalam keluarga. Tugas utama keluarga dalam pendidikan anak sebagai peletak dasar pendidikan akhlak dan pandangan hidup keagamaan. Sifat dan tabiat anak sebagian besar diturunkan dari kedua orang tuanya dan dari anggota keluarga lainnya. Melihat peran penting pendidikan keluarga dalam membentuk sifat kepribadian anak, maka tidak berlebihan bila Sidi Gazalba mengkategorikan pendidian lingkungan keluarga sebagai lembaga pendidikan primer, utamanya untuk masa bayi dan masa kanak-kanak sampai usia sekolah (Ramayulis, 2012: 320).

Suatu hal tidak bisa dipungkiri kondisi seperti sekarang ini, di berbagai sektor kehidupan telah terjadi pergeseran atau perubahan. Perubahan itu termasuk keluarga dalam segala peranannya. Keluarga menjadi sentral pendidikan bagi anak selanjutnya. Namun orang tua yang berprofesi sebagai wanita tunasusila tentu tidak dapat memperhatikan anak secara penuh, sebab waktu orang tua telah dihabiskan untuk pekerjaannya. Dengan demikian anak merasa sangat sengsara, tidak bahagia, dan memberontak, lalu menghibur diri terjun dalam dunia pelacuran.

Ketiga: Faktor Lingkungan Masyarakat. Latar belakang pendidikan merupakan masalah paling utama setiap individu. Melalui modal pendidikan, individu atau kelompok masyarakat dapat bertindak sesuai aturan atau norma yang berlaku dalam masyarakat. Pendidikan masyarakat menjadi lingkungan ketiga setelah keluarga dan sekolah. Pendidikan dialami dalam masyarakat telah mulai ketika anak-anak setelah lepas dari asuhan keluarga dan berada di luar pendidikan sekolah.

Pemahaman sekarang yang berkembang adalah menekankan pendidikan pada lingkungan sekolah, sehingga sekolah mendapat perhatian yang cukup besar, sementara pendidikan keluarga dan masyarakat kurang mendapat perhatian, atau cenderung terabaikan Sebagai konsekuensinya, apabila terjadi suatu ketidakselarasan atau penyimpangan pendidikan yang berlangsung dengan tujuan yang ditetapkan, maka sekolah mendapatkan sorotan yang paling tajam. Inilah yang kemudian membuat situasi pendidikan terlihat pincang, artinya terjadi ketidakseimbangn antara pendidikan keluarga, sekolah dan masyarakat (Nizar, 2002).

Dengan demikian pengaruh pendidikan masyarakat tampaknya mempunyai makna yang luas, seperti pembentukan kebiasaan-kebiasaan, pembentukan pengetahuan, sikap dan minat, maupun pembentukan kesusilaan dan keagamaan berasal dari pengaruh lingkungan masyarakat.

Menurut Saptari dalam Suyanto (2010), paling tidak ada tiga factor yang mendorong seseorang menjadi pelacur. Pertama, karena keadaan ekonomi atau kondisi kemiskinan rumah tangga perempuan pelacur. Kedua, karena pandangan tentang seksualitas yang cenderung menekankan arti pentingkeperawanan, sehingga tidak member kesempatan bagi perempuan 
yang sudah tidak perawan kecuali masuk ke dalam peran tersebut. Ketiga, karena dengan kekerasan atau paksaan.

\section{Upaya Penanggulangan Prostitusi}

Prostitusi merupakan salah satu bentuk penyakit masyarakat yang sudah ada sejak sejarah kehidupan manusia sampai sekarang, dan perlu ditanggulangi dengan penuh kesungguhan. Dewasa ini sudah dilakukan usaha-usaha ke arah penanggulangan pelacuran, sekalipun melalui proses yang sulit. Secara umum usaha untuk mengatasi masalah tuna susila ini dapat dibagi menjadi dua yaitu: Pertama, usaha yang bersifat preventif, dan kedua, usaha yang bersifat represif dan kuratif (Kartono, 2009).

Usaha yang bersifat preventif antara lain berupa: (a) Penyempurnaan perundang-undangan mengenai larangan pelacuran, (b) Intensifikasi pemberian pendidikan keagamaan dan kerohanian, untuk memperkuat keimanan terhadap nilai-nilai religius dan norma kesusilaan, (c) Menciptakan bermacam-macam kesibukan dan kesempatan rekreasi bagi anak remaja untuk menyalurkan kelebihan energinya, (d) Memperluas lapangan kerja bagi kaum wanita sesuia dengan kodrat dan bakatnya, (e) Penyelenggaraan pendidikan seks dan pemahaman nilai perkawinan dalam kehidupan keluarga, (f) Pembentukan badan atau tim koordinasi dari semua usaha penanggulangan pelacuran yang dilakukan oleh beberapa instansi sekaligus mengikutsertakan masyarakat lokal untuk membantu melaksanakan kegiatan pencegahan atau penyebaran pelacuran, (g) Penyitaan terhadap buku-buku dan majalah-majalah cabul, gambargambar porno, film-film biru dan sarana-sarana lain yang merangsang nafsu seks, (h) Meningkatkan kesejahteran rakyat pada umumnya.

Sedangkan usaha yang bersifat represif dan kuratif dimaksudkan sebagai kegiatan untuk menekan (menghapuskan, menindas), dan usaha menyembuhkan para wanita dari ketunasusilaannya. Usaha tersebut antara lain berupa hal-hal berikut. Pertama: Melalui lokalisasi yang sering disalah tafsirkan sebagai legalisasi, orang melakukan pengawasan/ control yang ketat demi menjamin kesehatan dan keamanan para pelacur serta lingkungannya. Kedua: Untuk mengurangi pelacuran, diusahakan melalui aktivitas rehabilitasi dan resosialisasi, agar mereka bias dikembalikan sebagai warga masyarakat yang susila. Rehabilitasi dan resosialisasi ini dilakukan melalui pendidikan moral dan agama, latihan-latihan kerja dan pendidikan keterampilan agar mereka bersifat kreatif dan produktif. Ketiga: Penyempurnaan tempat-tempat penampungan bagi para wanita tuna susila yang terkena razia, disertai pembinaan yang sesuai dengan bakat dan minat masing-masing. Keempat: Pemberian suntikan dan pengobatan pada interval waktu yang tetap untuk menjamin kesehatan para prostitue dan lingkungannya.

Kelima: Menyediakan lapangan kerja baru bagi mereka yang bersedia meninggalakn profesi pelacuran dan mau memulai hidup susila. Kenam: Mengadakan pendekatan terhadap pihak keluarga para pelacur dan masyarakat asal mereka mau menerima kembali mantan wanita tunasusila itu untuk memulai hidup baru. Ketujuh: Mencarikan pasangan hidup yang permanen/ suami bagi mantan wanita tunasusila untuk membawa mereka ke jalan yang benar. Kedelapan: Mengikutsertakan mantan wanita tunasusila dalam usaha transmigrasi, dalam rangka pemerataan penduduk di tanah air dan perluasan kesempatan kerja bagi kaum wanita.

Dalam sumber yang berbeda, disebutkan bahwa penanggulangn prostitusi di Indonesia dilakukan oleh beberapa departemen seperti Departeman Sosial dan alat penegak hukum seperti Satpol PP dan Polri (Soedjono, 1974: 119). Upaya yang dilakukan antara lain sebagai berikut: Pertama: Melarang pelacuran melalui peraturan yang diikuti dengan tindakan razia dan merehabilitasi yang masih dapat ditolong dengan ditampung di tempat-tempat penampungan 
dan tempat-tempat latihan kerja. Kedua: Mengadakan pencatatan tempat-tempat bordir dan tempat-tempat lainnya dengan maksud mengadakan pengawasan kesehatandan mengurangi jumlah pelacuran liar yang membahayakan. Ketiga: Melokalisir dalam suatu tempat di luar keramaian kota dengan diikuti usaha-usaha rehabilitasi mental dan pendidikan serta pengetahuan agama, latihan kerja dan lain-lain.

Berdasarkan paparan di atas dapat dipahami bahwa aktifitas prostitusi sangat perlu dicegah dan dihentikan melalui usaha yang sungguh-sungguh oleh semua pihak, agar permasalahannya cepat terselesaikan. Perilaku prostitusi sangat berbahaya tidak saja pada pelakunya, tetapi juga kepada keluarganya, dan masyarakat lingkungannya.

\section{Kesehatan Mental dalam Islam}

Kesehatan mental dalam kehidupan manusia merupakan masalah yang amat penting karena menyangkut kualitas dan kebahagiaan manusia. Tanpa kesehatan yang baik, orang tidak akan mungkin mendapatkan kebahagiaan dan kualitas sumber daya manusia yang tinggi. Hal itu disebabkan kesehatan mental masuk dalam segala aspek dan aktifitas kehidupan manusia, mulai dari kehidupan pribadi, keluarga, sosial, politik, agama serta sampai pada bidang pekerjaan dan profesi (Jaya, 2002: 68). Selanjutnya disebutkan bahwa kemajuan ilmu pengetahuan dan teknologi tidak dapat menjamin kualitas dan kebahagiaan manusia. Akan tetapi kualitas dan kebahagiaan itu sangat ditentukan oleh faktor kejiwaan, kesehatan dan keberagamaan yang dimiliki individu. Di samping itu kesehatan mental berupaya memecahkan segenap keruwetan batin manusia yang disebabkan oleh berbagai kesulitan hidup dan sekaligus berusaha memperoleh kebersihan jiwa, dalam pengertian tidak terganggu oleh berbagai ketegangan, ketakutan dan konflik (Akhyar, 2011: 133).

Lebih lanjut Zakiah Daradjat (2004: 7) mengemukakan: Kesehatan mental adalah suatu ilmu pengetahuan yang berpautan dengan kesejahteraan dan kebahagiaan manusia yang mencakup semua bidang hubungan manusia, baik hubungan dengan diri sendiri, maupun hubungan dengan orang lain, hubungan dengan alam dan lingkungan, serta hubungan dengan Tuhan.

Berdasarkan pendapat di atas dapat dipahami bahwa adanya pandangan dan wawasan yang lebih luas dalam memandang manusia. Manusia telah dipandang sebagai makhluk dengan empat dimensi sehat, yaitu sehat dalam dimensi psikologis, dimensi fisik, sosial, dan religius, dengan penekanan pada masalah kesejahteraan dan kebahagiaan hidup dalam konteks hubungan secara horizontal dan vertikal.

Jika dilihat dari segi kondisi jiwa, maka kesehatan mental menurut Zakiah Daradjat (1999:13) adalah terwujudnya keharmonisan yang sungguh-sungguh antara fungsi-fungsi jiwa, serta mempunyai kesanggupan untuk menghadapi problem-problem biasa yang terjadi, dan merasakan secara positif kebahagiaan dan kemampuan dirinya.

Pendapat di atas menekankan pentingnya terwujud kondisi jiwa yang dilandasi oleh keharmonisan fungsi-fungsi jiwa. Adanya kerja sama yang harmonis antara fungsi-fungsi jiwa tersebut, akan terbina kesiapan mental dalam menghadapi berbagai perubahan yang terjadi, sehingga tidak mengakibatkan kegelisahan dan kegoncangan jiwa.

Dari beberapa rumusan kesehatan mental di atas, dapat dilihat tanda-tanda atau karakteristik orang yang bermental sehat. Sebagaimana disampaikan oleh Samuel Soeitoe (1992: 74) bahwa orang yang bermental sehat tidak menunjukkan gejala-gejala penyimpangan mental. Seorang yang sehat mentalnya adalah lebih dari itu. Ia pandai menyesuaikan dirinya dengan diri 
sendiri dan dengan lingkungannya dengan penuh kepuasan dan kegembiraan. Ia menunjukkan tingkah laku yang tidak dibuat-buat, dapat diterima oleh lingkungannya dan olehnya sendiri, ia mempunyai kesanggupan dan kemampuan untuk menghadapi dan menerima kenyataankenyataan hidup.

Dengan demikian orang yang bermental sehat dalam Islam setidaknya terdapat empat tolak ukur, yaitu: Pertama, bebas dari gangguan dan penyakit jiwa, kedua, mampu secara luwes menyesuaikan diri dan menciptakan hubungan antar pribadi yang bermanfaat dan menyenangkan, ketiga, mampu mengembangkan potensi-potensi pribadi (bakat, minat, sikap, sifat dan sebagainya) yang baik dan bermanfaat bagi diri dan lingkungannya, keempat, beriman dan bertakwa kepada Allah Swt dan berupaya menerapkan tuntunan agama dalam kehidupan sehari-hari.

Bagi individu yang bermasalah dalam kesehatan mentalnya, maka dapat diberikan bimbingan yang berkisar pada pencapaian empat dimensi sehat sebagaimana telah disebutkan di atas. Pertama: Bimbingan Kesehatan dalam Bidang Fisik. Bimbingan fisik merupakan pembinaan yang diarahkan untuk melakukan kegiatan rolah raga. Kebiasaan ini baik untuk diterapkan sebab selain membuat tubuh bugar, rasa jenuh dan stres juga bisa dikikis menjadi terapi dalam bimbingan fisik. Bimbingan fisik adalah serangkaian usaha melalui bimbingan penanaman kedisiplinan yang dapat dilakukan melalui latihan-latihan jasmani seperti olah raga. Disamping itu memberikan pemahaman kepada individu untuk menjaga, merawat dan meningkatkan kesehatan melalui pembiasaan hidup bersih. Bimbingan kesehatan fisik tersebut akan menjadikan ketahanan tubuh dalam menghadapi berbagai hambatan dan rintangan kehidupan.

Kedua: Bimbingan Kesehatan dalam Bidang Psikologis. Kegiatan bimbingan kesehatan psikologis merupakan rangkaian kegiatan mengarah pada upaya penyembuhan kondisi mental (psikologis) dan mengembangkan kemampuan penyesuaian diri baik dengan dirinya sendiri, dengan orang lain, dengan alam lingkungannya serta dengan Tuhannya. Di samping itu memiliki kemampuan mengatasi masalahnya sendiri dan dapat menikmati ketenangan hidup.

Ketiga: Bimbingan Kesehatan dalam Bidang Sosial. Tahap ini merupakan kegiatan bimbingan bersifat dua arah. Pertama mempersiapkan penerima pelayanan (wanita tunasusila yang dibina) agar dapat berinteraksi penuh ke dalam kehidupan masyarakat secara normatif. Kedua mempersiapkan keluarga mereka agar dapat menerima dan mengajak untuk berinteraksi dalam kegiatan masyarakat. Jadi, tahap bimbingan sosial ini mengarah pada penerima pelayanan itu sendiri dari masyarakat dimana mereka akan hidup setelah dibina di panti rehabilitas. Pembinaan terhadap masyarakat luas agar mereka dapat menerima dan memperlakukan eks wanita tunasusila menjadi bagian dari masyarakat. Akan tetapi tampaknya masih sangat kurang efektif. Hal ini disebabkan pembinaan terhadap masyarakat tersebut memerlukan biaya yang tidak sedikit. Untuk mengantisipasi kendala tersebut, maka diperlukan kerja sama atau koordinasi antara pihak panti rehabilitasi dengan pihak-pihak lain.

Koordinasi dengan berbagai perusahaan dimaksudkan untuk mempersiapkan hasil pembinaan panti rehabilitasi agar dapat di tampung diberbagai perusahaan yang ada sesuai dengan profesi dan keterampilan masing-masing penerima pelayanan. Dengan demikian, maka pihak panti melakukan kerja sama dengan berbagai perusahaan untuk dapat menerima tenaga kerja yang telah dibina tersebut. Termasuk pula koordinasi dengan pihak keluarga atau orang tua penerima pelayanan, diharapkan agar para orang tua atau pihak keluarga dapat menerima kembali kehadiran mereka dilingkungan keluarga masing-masing dan diperlakukan secara wajar. 
Keempat: Bimbingan Kesehatan dalam Bidang Spiritual (Agama). Keyakinan terhadap agama yang menjadi bagian dari unsur-unsur kepribadian itu, akan mengatur sikap dan tingkah laku seseorang secara otomatis dari dalam, fungsi dan peran agama tersebut dapat memberikan kontribusi yang cukup besar untuk menghindari sifat-sifat negatif yang dialami oleh para wanita tunasusila.

Pembinaan kehidupan moral dan agama lebih banyak terjadi melalui pengalaman hidup dari pada pendidikan formil dan pengajaran di sekolah, karena nilai-nilai moral dan agama yang akan menjadi pengendali dan berpengaruh dalam kehidupan manusia adalah nilai-nilai yang masuk dan terjalin ke dalam pribadinya (Daradjat, 1996).

Selanjutnya Daradjat (1983) menambahkan bahwa pengertian tentang moral, belum dapat menjamin adanya tindakan moral. Banyak orang yang tahu bahwa suatu perbuatan adalah salah, tetapi dilakukannya juga perbuatan tersebut. Moral bukanlah suatu pelajaran yang dapat dicapai dengan mempelajarinya saja, tanpa membiasakan hidup bermoral dari kecil. Moral itu tumbuh dari tindakan kepada pengertian dan tidak sebaliknya.

Selain empat macam bimbingan kesehatan tersebut di atas, juga diberikan bimbingan keterampilan kepada eks wanita tunasusila. Bimbingan keterampilan lebih diarahkan untuk mengetahui dan menguasai suatu bidang keterampilan. Ketrampilan tersebut diharapkan akan bermanfaat setelah keluar dari pembinaan tersebut. Jenis keterampilan diajarkan seperti menjahit pakaian, menyulam, memasak dan lain-lain.

\section{Kesimpulan}

Berdasarkan uraian yang telah dipaparkan di atas, maka dapat ditarik beberapa kesimpulan. Pertama: Alasan seseorang yang berprofesi sebagai wanita tunasusila adakalanya karena terpaksa (faktor eksternal) misalnya karena himpitan ekonomi, sulitnya mencari pekerjaan, terjebak oleh tipuan agen tenaga kerja, dan lain-lain. Selain itu, ada pula yang melakukannya karena kemauan sendiri (faktor internal). Bagi yang sudah terlanjur berbuat, biasanya berpendapat sudah tidak ada lagi yang dapat dibanggakan dalam dirinya, maka ia akan mencari pelampiasan untuk tetap melakukan perbuatan amoralnya itu.

Kedua: Wanita tunasusila yang menjalankan profesinya secara terpaksa akan menimbulkan gangguan psikologis berupa dihantui perasaan bersalah, putus asa, dan menurunnya rasa percaya diri sehingga merasa sungkan dalam bergaul dengan masyarakat. Sedangkan yang menjalankan profesinya secara tidak terpaksa akan menimbulkan efek kecanduan dan merasa tidak pernah puas dengan pasangan seks sebelumnya, sehingga ia akan terus mencari pasangan yang sesuai dengan kriterianya.

Ketiga: Kepada para mantan wanita tunasusila diberikan beberapa bimbingan agar mereka bisa terlepas dari kegiatan prostitusi. Bimbingan yang dimaksud adalah berupa bimbingan untuk mendapatkan kesehatan psokologis, fisik, sosial dan bimbingan agama. Di samping itu juga dibekali dengan bimbingan keterampilan.

\section{DARTAR PUSTAKA}

Akhyar, Saiful. (2011). Konseling Islamidan Kesehatan Mental. Bandung: Citapustaka Media Perintis.

Daradjat, Zakiah. (1983). Peranan Agama dalam Kesehatan Mental. Jakarta: Gunung Agung

(1996). Ilmu Jiwa Agama. Jakarta: Bulan Bintang.

. (1999). Kesehatan Mental. Jakarta: Haji Masagung. 
UNISIA, Vol. XXXVII No. 82 Januari 2015

(2004). Kesehatan Mental: Peranannya dalam Pendidikan dan Pengajaran. Jakarta:

Gunung Agung.

Djubaedah, Neng (2003). Pornografi \&Pornoaksi Ditinjau dari Hukum Islam. Jakarta: Timur: Kencana

Jaya, Yahya (2002). Menuju Optimalisasi Kesehatan Mental. Padang: Angkasa Raya.

Kartono, Kartini (2009). Patologi Sosial, Jilid I. Jakarta: Raja Grafindo Persada.

Nizar, Syamsul (2002). Filsafat Pendidikan Islam: Pendekatan Historis, Teoritis dan Praktis. Jakarta: Ciputat Press.

Poerwadarminta (1987). Kamus Besar Bahasa Indonesia, Jakarta: tp.

Ramayulis. (2012). Ilmu Pendidikan Islam. Jakarta: Kalam Mulia.

Soedjono, D. (1974). Pathologi Sosial. Bandung: Alumni.

Soeitoe, Samuel. (1992). Psikologi Pendidikan, Jilid II. Jakarta: Lembaga Penerbit Fakultas Ekonomi Universitas Indonesia.

Suyanto, Bagong. (2010). Masalah Sosial Ana., Jakarta: Kencana.

Suyanto, Bagong. "Prostitusi Online dan Penanganannya". Padang: Padang Ekspres, 30 April 2015

Undang-Undang RI , No. 6 tahun 1974, tentang Kesejahteraan Sosial 